\title{
PRACTICAL GUIDE TO AVOIDING PITFALLS IN RESEARCH PAPER WRITING
}

\author{
Matthew O. Iwuchukwu \\ Department of Foreign Languages and Literary Studies, University of Nigeria, Nsukka \\ Email: matthew.iwuchukwu@ unn.edu.ng; moiwuchukwu@yahoo.com
}

DOI: 10.47760/cognizance.2021.v01i03.001

\begin{abstract}
Pitfalls in research paper writing is a very important subject matter in academia, especially in research in arts and social sciences, but there is a dearth of literature focusing exclusively on the issue of pitfalls in scholarly research. Thus, the objective of this descriptive study is to examine the major pitfalls in research paper writing and how to avoid them. The study elucidates several pitfalls in the writing of a research paper, a Master's or Ph.D thesis/dissertation, that is, the inadequacies observed in the following components of a typical research work: research title, abstract, introduction, literature review, methodology, data presentation and discussion. Others are incomplete and improper referencing as well as inadequate use of language and conclusion. The paper also highlights some research tips to avoid the pitfalls and enhance research originality, capacity and acceptability at the local and international levels of readership. Based on the above, the study encourages postgraduate students and young researchers to adhere strictly to the rules of approved referencing styles such as the American Psychological Association (APA) and Modern Language Association (MLA), while observing also the editorial guidelines of reputable scholarly journals, research institutions or research grant donor agencies.
\end{abstract}

Keywords: Research paper, writing, avoiding pitfalls, referencing, originality, relevance.

\section{INTRODUCTION}

This study on pitfalls in research paper writing is intended for postgraduate students and young research scholars of various subjects in the arts and social sciences. The title "Practical Guide to Avoiding Pitfalls in Research Paper Writing" underscores the importance and relevance of research within the university system in the sense that getting involved in research and development programmes is one of the primary responsibilities of university lecturers and postgraduate students in Nigeria, Africa and beyond. 
What is the meaning of research? According to Rajasekar et al, "research is a logical and systematic search for knowledge", that is, a search for new and useful information on a particular topic with a view to finding solutions to scientific and social problems through objective and systematic analyses. They rightly point out that there are vast areas of research in "science and other disciplines such as languages, literature, history and sociology. [...]. Applying the outcome of research for the refinement of knowledge in other subjects, or in enhancing the quality of human life also becomes a kind of research and development" (Research Methodology 2-3).

In other words, research means to carefully do a detailed study of a specific problem, by using appropriate methods in the area of investigation. Thus, a good research paper makes original contribution to the existing knowledge in the scholar's area of specialization. The quantity and quality of existing studies on research methods in circulation justify the importance and relevance of research within and outside the Nigerian tertiary education system. Some of them are readily available and accessible online. Among the current and interesting publications on the subject matter are the following: Onyemelukwe's "Plagiarism or Academic Theft: Typology, Indicators and the Way Out”, Balida's Research Methods, Ezeoha and Ogba's A Simple Guide to Originality in Research: Perspective on Anti-Plagiarism and Originality Implementation, Iwuchukwu’s “Literature Review and Use Benjamin Bloom's Taxonomy”, and Shields and Rangarajan's A Playbook for Research Methods: Integrating Conceptual Frameworks and Project Management. Others are Tijani’s Guide pratique pour la rédaction de mémoire et la méthodologie de la recherche, Leedy and Ormrod's Practical Research-Planning and Design, Nwabueze's Research Methods An Integrated Approach, Dawson's A Practical 


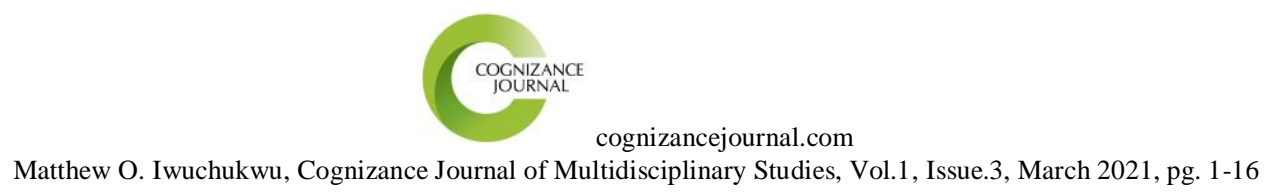

Guide to Research Methods, Research Methodology by Rajasekar et al, Guidère's Méthodologie de la recherche, Adogbo and Ojo's Research Methods in the Humanities, etc.

It is important to note that these publications deal with the various components of a research plan such as literature review, theoretical procedures, conduct of surveys, interviews, experiments and tests. Various stages of research are discussed by the authors. Essentially, their works elucidate the role of research methods in the process of collecting data, samples, and finding a solution to a research problem, but their focus is not on pitfalls in research paper writing. It is, therefore, expected that the present study will help to fill this knowledge gap, its primary objective being to explore the major pitfalls in research paper writing and how to avoid them to enhance research originality and capacity.

What is a pitfall? What does it mean within the framework of writing a research paper? Pitfall is defined as "a danger or difficulty, especially one that is hidden or not obvious at first" (Oxford Advanced Learner's Dictionary) and figuratively, it is views as "a potential problem, hazard, or danger that is easily encountered but not immediately obvious" (Oxford Dictionary of English). In research paper writing, a pitfall means an avoidable mistake, an error, or a bad habit on the part of the researcher, but generally unknown to the latter. It is expected that being aware of such pitfalls will go a long way in helping the researcher to avoid them in writing a top-notch journal article, a thesis or a dissertation at the both the Master's and Ph.D degree levels. Professor P. Balaram asserts that a "Ph.D. degree is a passport to a research career. The Ph.D. period often influences a research scholar to make or to break in a scientific career. Here one reaches the frontier of knowledge and begins in earnest the lifelong task of learning how to do research" (Cited by Rajasekar et al, Research Methodology 3). 


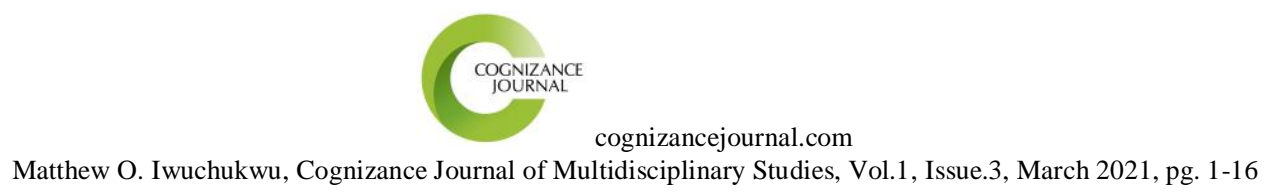

Pitfalls in research paper writing are rather too many in number to be dealt with in a journal article, hence there is need to delimit the scope of the study by addressing only those we consider to be the most important. Specifically, this study will make an attempt to discuss the major pitfalls and how to avoid them in writing the following components of a manuscript: title, abstract, introduction, literature review, methodology, data presentation and discussion, referencing, use of language, and conclusion.

\section{Inadequate Research Title}

A title is one of the most important constituents of a research paper, a thesis, a dissertation, a book or an essay. Some researchers are clueless when it comes to choosing an appropriate title for their work, that is, selecting an identifying name that is clear and relevant to the topic and content of a research paper. They tend to forget that a good title should succinctly address a subject matter of discussion and add substance to their research work. The researcher is expected to formulate a good title through linking a problem statement to the topic and "niche area" (area expertise or specialization). In other words, a good title should be relevant to both the topic and niche area of an academic discipline as the title below illustrates:

\section{Example 1:}

Research Title: 'Literature review and use Benjamin Bloom's Taxonomy"1 : Iwuchukwu's published journal article.

Topic: Literature review.

Niche Area: Research methods. 


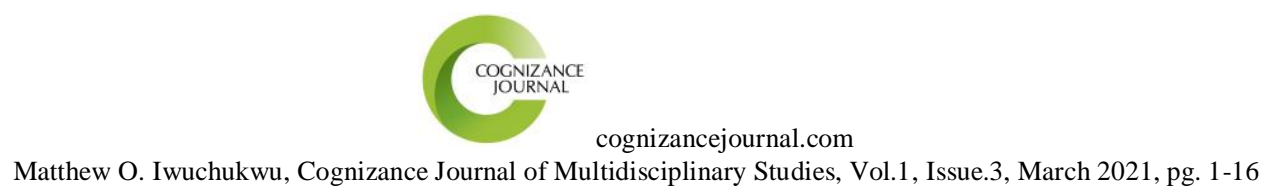

Example 2:

Research Title: L'Inscription de l'espace dans les romans de Sony Labou Tansi/Inscription of space in Sony Labou Tansi's Novels ${ }^{2}$ : Okolo's published Ph.D Thesis/Book.

Topic: L’Espace romanesque/Fictional space.

Niche Area: Le Roman francophone africain/Francophone African novel.

In addition, a good title should be original, concise, descriptive and to the point, containing the fewest possible words that adequately situate the purpose and problem of a research paper, thereby reflecting its originality, innovativeness and contribution to knowledge. According to Ezeoha and Ogba, a title "presents the picture of what the research is all about, the direction, feasibility and goal of the research", noting that an editor or a publisher of a peer reviewed journal or book may be compelled to reject a manuscript based on the inadequacy of title (34-35). Every research scholar should, therefore, strive to succinctly construct a title of about 13-18 words relating to the topic, niche area and problem that a study has set out to address. However, research bodies or organizations reserve the right to stipulate their own requirements in line with their specific needs and policies. On this note, the Revised Postgraduate Studies Regulation of the University of Nigeria states as follows: "The number of words in the title of thesis or project report shall not exceed twenty five" (60).

\section{- Lack or Inadequacy of Abstract}

The construct of a title is related to writing an abstract. It has been observed that a number of published and unpublished research papers do not have abstracts and that some researchers tend to reproduce the content of a conclusion in the abstract. Technically, although both of them 


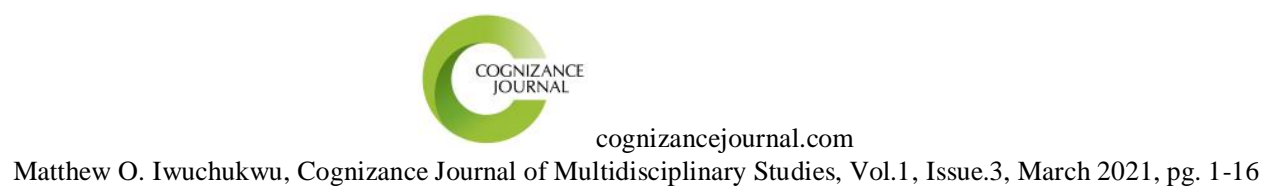

are interrelated, abstract and conclusion are two different parts of a research paper, each having a specific function to perform in the manuscript. The researcher is expected to clearly present in 200-250 words the following essential constituents of a good abstract: problem, objectives, methodology, findings, and sometimes recommendation (POMFR).

\section{Inadequate Introduction}

The introduction of a Master's or a Ph.D thesis/dissertation is known as and called chapter one, that is, the foundational work that normally contains the background of the study and others such as the theoretical/conceptual framework, statement of the problem/objective, hypothesis, significance, scope and limitation of a study as well as definition of terms. Unfortunately, some postgraduate students do not adhere to the basic principles of writing a good introduction, especially with regard to their failure to clearly state the rationale behind their research project as well as the resolved and trending issues in the area of investigation. Specifically, a good introduction (chapter one) is expected to address a knowledge gap to filled by the study, but the review of related literature and methodology have to be discussed in detail in chapters two and three respectively.

It has also been observed that some postgraduate students and young researchers fail to clearly state research aim, objectives and methodology. The researcher should express in broad terms the aim or what he or she hopes to achieve at the end of the project, while the objective should be written in strong positive terms what steps will be taken to achieve the desired outcome. Thus, action verbs should be used in the formulation of research objectives, and the 
cognizancejournal.com

Matthew O. Iwuchukwu, Cognizance Journal of Multidisciplinary Studies, Vol.1, Issue.3, March 2021, pg. 1-16

statement should be concise, measurable and itemized. Ezeoha and Ogba recommend that the examples in the box below be considered in the formulation of objectives:

\begin{tabular}{|c|c|}
\hline For Quantitative Research & For Qualitative Research \\
\hline To estimate & To examine \\
\hline To determine & To review \\
\hline To find & To discuss \\
\hline To analyze & To narrate \\
\hline To provide & To address \\
\hline To forecast & To verify \\
\hline To experiment & To trace \\
\hline To evaluate & To establish \\
\hline To predict & To disprove \\
\hline
\end{tabular}

Source: Ezeoha and Ogba, A Simple Guide to Originality in Research (98)

The above recommendation of terms notwithstanding, I suggest that the following weak or immeasurable verbs be avoided in the statement of research objectives: consider, enquire, acquire, teach, learn, know, understand, appreciate, perceive, etc.

In addition, there should be enough reference to the literature review and methodology in the introduction and research proposal, but the development of both segments of research methods has to be done in chapters two and three of a thesis or dissertation respectively. 


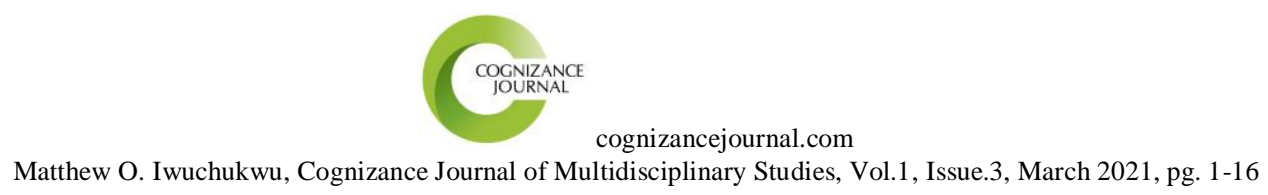

\section{Lack or Inadequacy of Literature Review}

Some completed and ongoing postgraduate theses or dissertations show lack of research or inadequate background knowledge before choosing a thesis topic, the review of related literature being one of the important processes of research methodology. Some researchers are clueless when it comes to finding literature that adds substance to their work. A good literature review comprises at least three parts, namely an introduction or the background of literature review, a body with a focus on the discussion of relevant scholarly sources, both print and electronic sources, and a conclusion that summarizes the discussion and shows a knowledge lacuna or gap to filled by the proposed study. According to Iwuchukwu,

The background knowledge acquired in the course of the research enables him or her to make useful connections between literature review and other parts of the research project, ensuring that the lacunae in the previously concluded research are addressed and that any possible gap is filled by the present study [...]. On the other hand, if there is no previously published material in the area, you also have to say so, explaining how your proposed research will fill this gap (438).

The literature being reviewed should, therefore, be organized around and related to the researcher's topic with particular reference to the problem being interrogated. Nwabueze explores four organizational methods of literature review as follows: "chronological arrangement, thematic arrangement, methodological arrangement and categorical arrangement" (44-46). A good literature review shows that the reviewer is familiar with the state of research in his or her area of investigation. In their own interest, postgraduate students and young scholars 


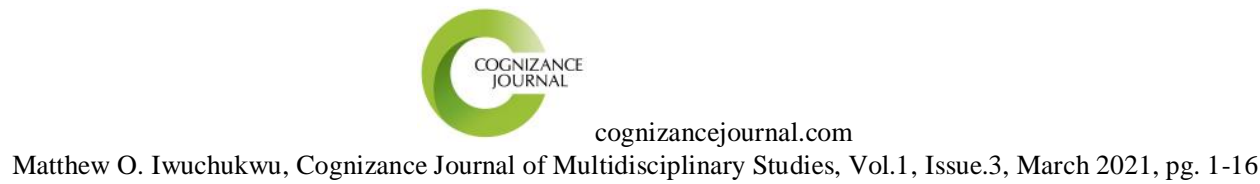

should, therefore, not rush into choosing their project topic and writing the manuscript without a solid foundational review of related literature.

\section{Inadequate research methodology}

Literature review (chapter two) and methodology (chapter three) are interrelated in the process of doing research and writing of a postgraduate thesis or dissertation. Research methods and research methodology are also interrelated in the process. The former is concerned with the various methods used by the researcher in the course of a study such as theoretical procedures and experimental studies, while the latter is a science or a systematic way of studying how to solve a problem, for example, through describing, analyzing, interpreting, explaining or predicting a phenomenon.

Failure to produce good results has been observed in a number of completed research works within the university system, due to lack of in-depth knowledge of relevant theories and methodologies or their inadequacies. Every researcher is expected to design and follow a suitable methodology for the problem that the proposed study has set out to address in line with the set objectives. Thus, the postgraduate student or research scholar or required to clearly present and use a suitable analytical approach in the writing of a thesis, a dissertation or a scholarly journal article. In literary criticism, for instance, Okolo's published Ph.D thesis, L'Inscription de l'espace dans les romans de Sony Labou Tansi/Inscription of space in Sony Labou Tansi's Novels, makes original contribution to knowledge in the sense that it establishes a trilling link between the writer's fictional space and social discourse on human rights activism through the use of sociocriticism (sociocritical approach). 


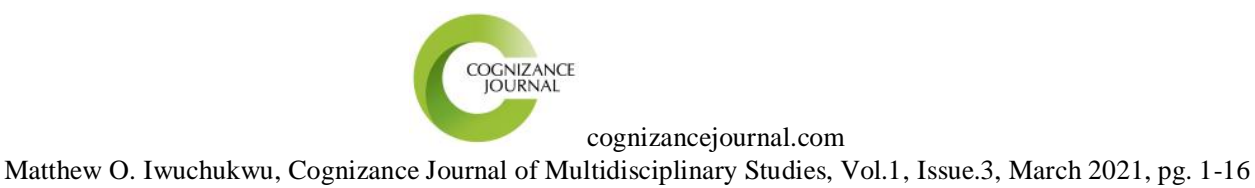

\section{Data Presentation, Analysis and Discussion Challenges}

Methodology is followed by data presentation, analysis and discussion that normally appear in the remaining chapters of a thesis or dissertation, that is, in chapter four and others. For instance, in Okolo's published Ph.D thesis on fictional space and discourse, chapters four and five deal with data presentation and analysis, while chapter six focuses on the discussion of findings. The discussion segment gives a more detailed insight into the issues emanating from the outcome of data analysis and their implications for possible applications to real life situations. Specifically, "La production de l'espace"/Creation of a new space in chapter six (151180) stems from the analysis and interpretation of Labou Tansi's peculiar spatial system and social discourse on human rights in Africa.

However, readers have noted that some completed research works show lack of strong data to support a thesis or problem statement and supporting statements. A good researcher should avoid the use of sweeping generalizations, padding flaws, subjective fallacies and statements without verifiable evidence. The research scholar should arm himself or herself with a solid evidential base to ensure that the relevant statements and arguments in the paper are backed up by relevant sources, with a view to enhancing the quality and relevance of research findings, conclusions and recommendations.

\section{Incomplete and Improper Referencing}

The comments and observations made by some research project supervisors, examiners and journal article reviewers reveal the inadequacy of works cited in number and currency, as 
Matthew O. Iwuchukwu, Cognizance Journal of Multidisciplinary Studies, Vol.1, Issue.3, March 2021, pg. 1-16

well as incomplete and improper referencing on the part of several postgraduate students and young scholars, especially in the data analysis and discussion segments of their research works ${ }^{3}$. It is pertinent to note that failure to cite all relevant sources used in a research paper is a serious ethical misconduct in academia. Any researcher who copies in whole or in part from other sources without clearly citing them in his or her study may be adjudged guilty of plagiarism or self-plagiarism with its attendant consequences. According to the international Committee on Publication Ethics (COPE),

plagiarism ranges from the unreferenced use of others' published and unpublished ideas, including research grant applications to submission under "new" authorship of a complete paper, sometimes in a different language. It may occur at any stage of planning, research, writing, or publication: it applies to print and electronic versions". COPE also argues that "Editors should not simply reject papers that raise questions of misconduct. They are ethically obliged to pursue the case ("Plagiarism" 45).

It has been observed that several postgraduate students and young scholars fail to cite or properly cite the various print and electronic sources they used in the writing of their research projects, some of them forgetting to add the sources appropriately credited to the list of "Works Cited". Onyemelukwe laments the escalating menace of various forms of plagiarism within and outside the Nigerian university system:

It is found that plagiarism is of four major types, namely self-plagiarism, accidental-plagiarism, deliberate plagiarism, and cyber-plagiarism. Another finding of this research is that a good number of people plagiarise out of 
Matthew O. Iwuchukwu, Cognizance Journal of Multidisciplinary Studies, Vol.1, Issue.3, March 2021, pg. 1-16

carelessness and ignorance of what it entails and, therefore, unintentionally even though ignorance of the law is no excuse. The effective ways to avoid plagiarism are principally to paraphrase, cite sources of information in the body of the work and reference them in Works Cited at the end following the prescribed model of reference ("Plagiarism or Academic Theft" 9).

Onyemelukwe's study also establishes that students, teachers, lecturers, academics and professors plagiarise or can plagiarise one's own or someone else's writing. On this note, postgraduate students and scholars who make use of translated versions of works in a target language should ensure that the authors of the original works, not the translator, are properly cited in their research projects. Students writing a Master's or Ph.D thesis/dissertation should also follow their supervisors' instructions and recommendations in their own (students') interest, effecting the correction of all possible errors and mistakes in the manuscript, and they should not be in a rush to complete their research work or academic programme.

Furthermore, the researcher should strive to adhere strictly to the rules of approved referencing styles such as the American Psychological Association (APA), Modern Language Association (MLA), etc. He or she should also consult and observe the editorial guidelines of reputable scholarly journals, research institutions or research grant donor agencies.

\section{Inadequate Use of Language}

English and French are viewed as global academic languages in which most postgraduate students and researchers disseminate their ideas and research findings throughout the world, both of them being the official languages of most countries and organizations in Nigeria, Africa and 


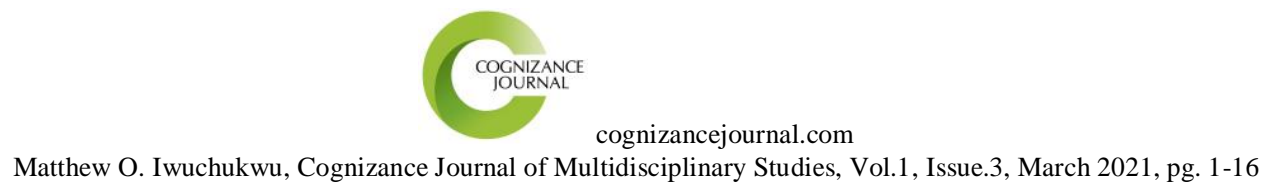

beyond. Over the years, they have been the languages of choice for most high impact factor ranked journals and research grant donor agencies. However, research papers are often rejected due to grammatical errors, spelling and punctuation mistakes, use of colloquial expressions or slangs in the manuscript, for example, "kids" and "booze" instead of "children" and "alcohol" or "beer" respectively, etc. Researchers should learn to avoid these blunders by reading attentively and revising their work thoroughly, this practice having been found to be an excellent remedy for any handicap in effective research paper writing. In other words, there is need to read, re-read and properly revise the manuscript. The American Psychological Association (APA) recommends the following tips of academic paper writing: Use the past tense or the presentperfect tense, vary sentence length, use specific language, avoid noun strings, jargon, anthropomorphism, wordiness, redundancy, etc. (Cited by Rao, The Use of English 6).

The researcher who writes in a foreign language like French should also ensure proper use of the five French accent marks in the writing of a scholarly article, a thesis or a dissertation: The following samples are drawn from the French language: ç - la cédille/cedilla, é - l'accent aigu/acute accent, ô/̂/̂â/ê - l'accent circonflexe/circumflex accent, à/è/ù - l'accent grave/grave accent, and $\ddot{e} / \mathrm{i}-$ l'accent tréma/trema accent. It is pertinent to mention that in Quebec (Canada), it is mandatory to put the accent marks on all appropriate capital letters written in French. Although this principle/practice is optional in France and Francophone African countries, I encourage all scholars and postgraduate students of French to borrow a leaf from Quebec and put accent marks on the relevant capital letters in French as follows: Ç, É, È Ê Ë Ô, Î, Â, À, Ù, İ. These capital letters are original, beautiful and much better than those without accent marks $(\mathrm{C}$, E, O, I A, U, I) in the French language. 
cognizancejournal.com

Matthew O. Iwuchukwu, Cognizance Journal of Multidisciplinary Studies, Vol.1, Issue.3, March 2021, pg. 1-16

\section{Inadequate Conclusion}

Some researchers tend to reproduce the content of an abstract in the conclusion and vice versa, although each of them is a distinct constituent of a typical research paper. A good conclusion is expected to succinctly summarize the arguments and content of a study.

\section{CONCLUSION}

Having made an attempt to define research and pitfall within the framework of research paper writing, the present study proceeds to discuss the major pitfalls in writing the following constituents of a research paper, a Master's or a Ph.D thesis/dissertation: inadequacies in the research title, abstract, introduction, literature review, methodology, data presentation and discussion. Others are incomplete and improper referencing as well as inadequate use of language and conclusion. In addition, the paper elucidates a number of actions designed for postgraduate students and young researchers to avoid the pitfalls and enhance research originality, capacity and acceptability at the local and international levels of readership.

Based on the above findings, the study encourages the researcher to adhere strictly to the rules of approved referencing styles such as the American Psychological Association (APA), Modern Language Association (MLA), etc. They should also consult and observe the editorial guidelines of reputable scholarly journals, research institutions or research grant donor agencies.

\section{NOTES}

1. Matthew O. Iwuchukwu. "Literature Review and Use Benjamin Bloom's Taxonomy". International Journal of Humanities and Cultural Studies, 23 (2015): 436-444. 
Matthew O. Iwuchukwu, Cognizance Journal of Multidisciplinary Studies, Vol.1, Issue.3, March 2021, pg. 1-16

2. Chinwe Jane Okolo. L'Inscription de l'Espace dans les Romans de Sony Labou Tansi. Beau Basin : Editions Universitaires Européennes. 2018. (Published Ph.D thesis supervised by Matthew O. Iwuchukwu and defended in the Department of Foreign Languages and Literary Studies, University of Nigeria, Nsukka, in 2017).

3. The author of this paper, Matthew O. Iwuchukwu, serves and has served as editorial consultant/board member in respect of the following high impact factor ranked international journals: Meta: Journal des traducteurs/Translators' Journal (Canada), Canadian Journal of African Studies/Revue canadienne des études africaines (Canada), European Scientific Journal (Portugal), Nordic Journal of Francophone Studies (Sweden), Cognizance Journal of Multidisciplinary Studies (Sweden), Neohelicon (Hungary) and Présence francophone (USA). Others are Revue de l'Association nigériane des enseignants universitaires de français (RANEUF), Nsukka Journal of Foreign Languages and Literary Studies (UNN), Nsukka Journal of the Humanities (UNN), Journal of Academic Excellence for the Humanities and Social Sciences (UNN), Calabar Studies in Languages (UNICAL), AGORA: A Journal of Foreign Language Studies (UNIUYO), Kaduna State University Journal of French (KASUJOF), Journal of Modern and European Languages and Literature (UNIZIK), JOTRANS: A Journal of Translation Studies (ABSU) and Open Journal of Linguistics and Literature (OJLL). In addition, Professor Iwuchukwu has successfully supervised several Master's and Ph.D theses or dissertations in French, literary and translation studies. 
cognizancejournal.com

Matthew O. Iwuchukwu, Cognizance Journal of Multidisciplinary Studies, Vol.1, Issue.3, March 2021, pg. 1-16

\section{References}

[1]. Balida, Don Anton Robles. Research Methods Handbook for Academic Researchers: A modular Approach. https://researchgate.net/publication/. 2018. Accessed on 4 February, 2021.

[2]. Committee on Publication Ethics (COPE). Guidelines on Good Publication Practice, https://publicationethics.org/guidance/Guidelines. 2018. Accessed on 29 January, 2021.

[3]. --------COPE Ethical Guidelines for Reviewers: Promoting Integrity in Scholarly Research and its Publication. 2017. https://doi.org/10.24318/cope. Accessed on 29 January, 2021.

[4]. Deuter, Margaret et al. Oxford Advanced Learner's Dictionary, Revised Edition, 2014. Print.

[5]. Oxford Dictionary of English. Electronic Version Download, 2015.

[6]. Ezeoha, Abel E.and Ike-Elechi Ogba. A Simple Guide to Originality in Research Perspective on Anti-Plagiarism \& Originality Implementation. Foreword by Engr. Prof.

[7]. F.I. Idike. Abakaliki: Vice-Chancellor's Office, Ebonyi State University, 2015. Print.

[8]. Iwuchukwu, Matthew O. "Literature Review and Use Benjamin Bloom's Taxonomy", International Journal of Humanities and Cultural Studies, 23 (2015): 436-444. Print.

[9]. ------- L'Espace dans le roman africain francophone: valeurs, visions et idéologies, Okigwe : Fasmen Educational and Research Publications (FERP). 2002. Print.

[10].Kittler, Markus G. A Template and Guide to Writing Academic Papers, April 2020.

[11].https://researchgate.net/publication/. Preprint. Accessed on 4 February, 2021.

[12].Leedy, P. \& Ormrod, J. Practical Research - Planning and Design. New York : Pearson. 2010. Print.

[13].Nwabueze, Emeka. Research Methods An Integrated Approach. Enugu: ABIC Books and Equip Ltd. 2009. Print.

[14].Okolo, Chinwe. L'Inscription de l'Espace dans les Romans de Sony Labou Tansi. Beau Basin : Editions Universitaires Européennes. 2018. Published Ph.D thesis defended in the Dept. of Foreign Languages and Literary Studies, University of Nigeria, Nsukka, in 2017.

[15]. Onyemelukwe, Ifeoma M. "Plagiarism or Academic Theft: Typology, Indicators and the Way Out". International Journal of Applied and Natural Sciences (IJANS). 2019. Accessed from https://www.researchgate.net/publication/341050084 on 22 December, 2020.

[16].Rajasekar, S. et al. (2006/2013). Research Methodology. Accessed from https:// www.semanticscholar.org/paper. Accessed on 3 January, 2021.

[17].Rao, V. Chandra Sekhar (2018). "The Use of English Language in Research", Journal for Research Scholars and Professionals of English Language Teaching, 82 (2018).

[18].Accessed from https://www.researchgate.net/publication/329655421 on 26 February, 2021.

[19].Tijani, Muftau A. Guide pratique pour la rédaction de mémoire et la méthodologie de la Recherche. Porto-Novo: Editions Sonou d'Afrique. 2011(First published in 2003).

[20].University of Nigeria. Revised Postgraduate Studies Regulation of the University of Nigeria, Nsukka: University of Nigeria, 2015. 